\title{
4D scanning: a diagnostic tool of choice for detection of fetal limb reduction defects
}

\author{
D Janga, ${ }^{1} 0$ Akinfenwa² \\ 1Department of Obstetrics and Gynaecology, Homerton University Hospital, London, UK; \\ 2Department of Fetal Medicine, Homerton University Hospital, London, UK
}

Correspondence to D Janga, deepa janga@yahoo.co.uk

\section{DESCRIPTION}

A 32-year-old primigravida, with low background risk at booking, referred to our fetal medicine department after a missing left lower limb in the fetus was diagnosed on scan at 26 weeks gestation. Hypoplastic left thigh and limb reduction defect were confirmed (figures 1 and 2) using 4D scan, and parents counselled. They remained committed to the pregnancy. Subsequent scans showed good growth and polyhydramnios. She underwent an emergency caesarean section at 41 weeks for fetal distress, and baby weighed $4175 \mathrm{~g}$. On examination, baby had absent left lower limb and ectopic left hemiscrotum. Skeletal survey showed aplastic left pelvic bone, absent tibia-fibula and hypoplastic femur. Karyotype was normal.
The finding of a limb reduction defect in an otherwise healthy baby can be very disappointing for the expectant parents. The upper limb is twice as commonly affected by reduction defects than the lower limb. ${ }^{1}$ In our case, the baby had a longitudinal defect (absence/severe hypoplasia of the long bones). Most upper limb defects are isolated events but those involving lower limbs are often part of more complex anomalies or syndromes. ${ }^{2}$ Possible causes include chromosomal anomalies, drugs (thalidomide, a classic example) and amniotic bands. Various anomalies can be caused by amniotic bands ranging from minor constrictions of digits to cleft lip and palate. The significance of an association between maternal factors and limb reduction defects is difficult to assess in retrospective studies. ${ }^{3}$

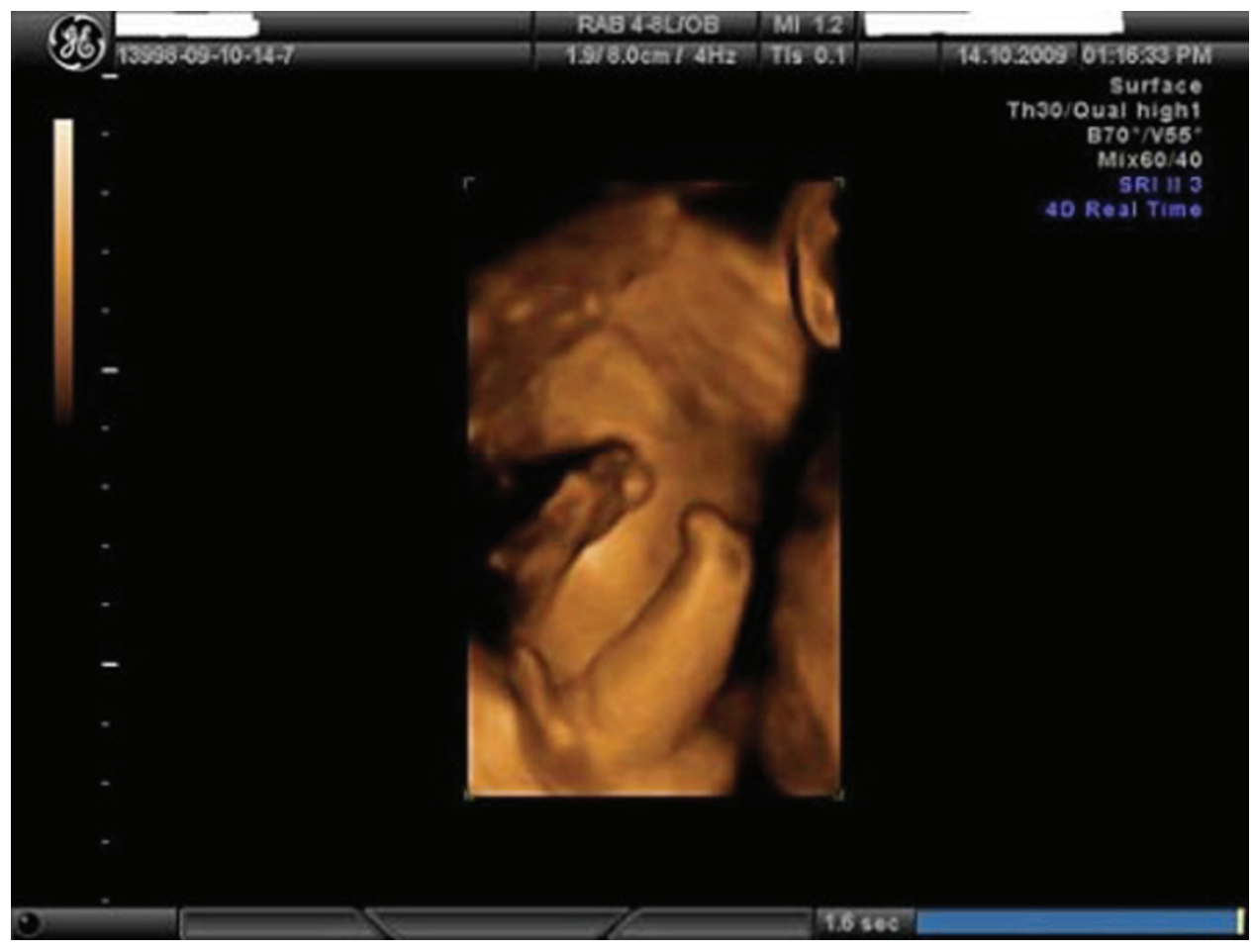

Figure $14 \mathrm{D}$ image of the limb reduction defect, in utero. 


\section{BMJ Case Reports}

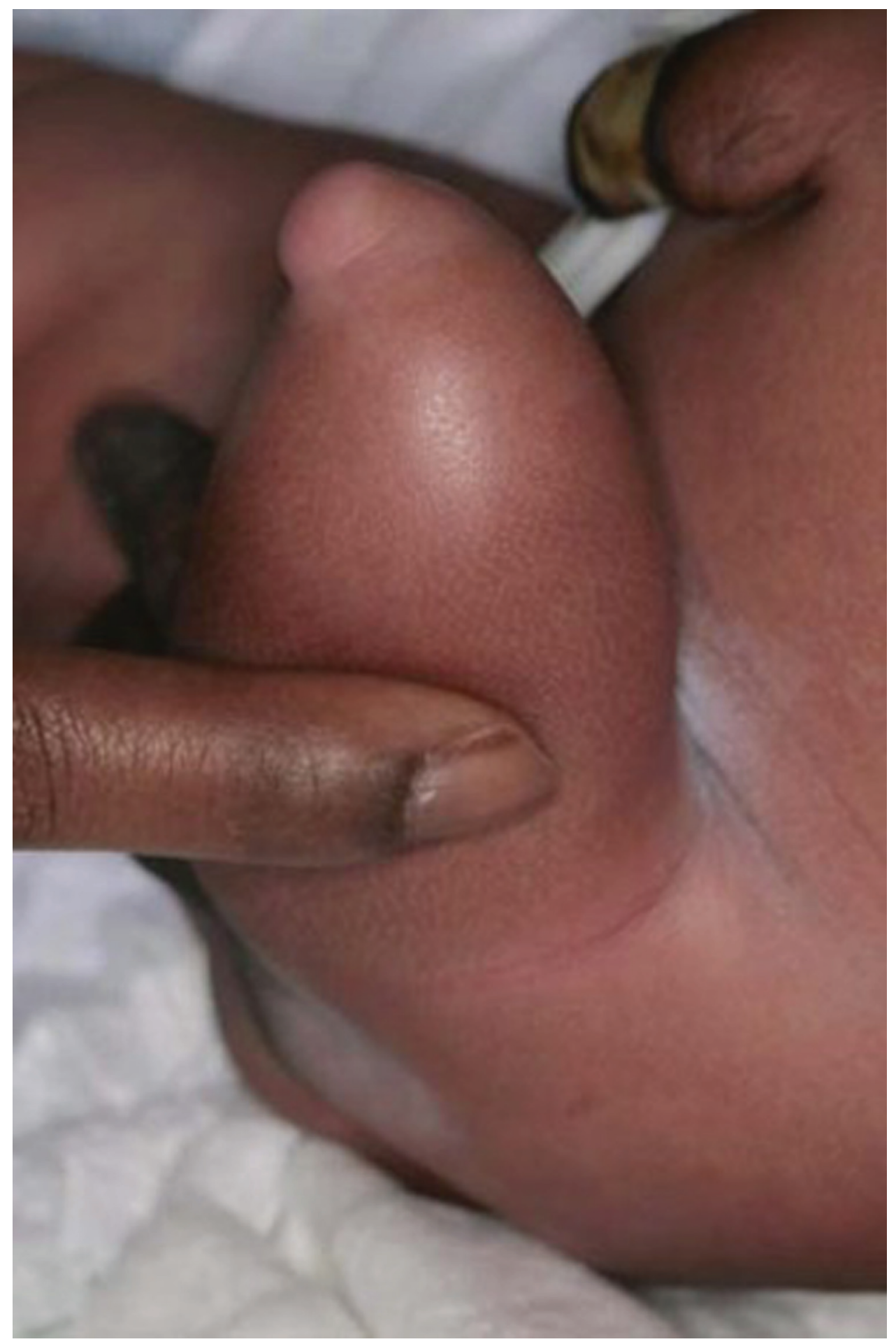

Figure 2 Postnatal image showing absent lower limb and hypoplastic femur.

Prospective studies would then be required to confirm any hypothesis regarding causation.

Acknowledgements The authors would like to thank the patient for agreeing to this case report.

Competing interests None.

Patient consent Obtained.

\section{REFERENCES}

1. Stoll C, Wiesel A, Queisser-Luft A, et al. Evaluation of the prenatal diagnosis of limb reduction deficiencies. EUROSCAN Study Group. Prenat Diagn 2000;20:811-18.

2. Stoll C, Alembik Y, Dott B, et al. Associated malformations in patients with limb reduction deficiencies. Eur J Med Genet 2010;53:286-90.

3. Werler MM, Bosco JL, Shapira SK. Maternal vasoactive exposures, amniotic bands, and terminal transverse limb defects. Birth Defects Res Part A Clin Mol Teratol 2009;85:52-7. 


\section{BMJ Case Reports}

This pdf has been created automatically from the final edited text and images.

Copyright 2011 BMJ Publishing Group. All rights reserved. For permission to reuse any of this content visit http://group.bmj.com/group/rights-licensing/permissions.

BMJ Case Report Fellows may re-use this article for personal use and teaching without any further permission.

Please cite this article as follows (you will need to access the article online to obtain the date of publication).

Janga D, Akinfenwa 0. 4D scanning: a diagnostic tool of choice for detection of fetal limb reduction defects. BMJ Case Reports 2011;

$10.1136 / \mathrm{bcr} .04 .2011 .4158$, date of publication

Become a Fellow of BMJ Case Reports today and you can:

- Submit as many cases as you like

- Enjoy fast sympathetic peer review and rapid publication of accepted articles

- Access all the published articles

Re-use any of the published material for personal use and teaching without further permission

For information on Institutional Fellowships contact consortiasales@bmjgroup.com

Visit casereports.bmj.com for more articles like this and to become a Fellow 